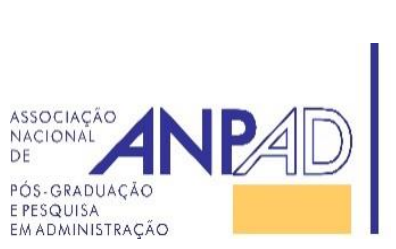

Available online at http://www.anpad.org.br/bar

BAR, Rio de Janeiro, v. 14, n. 4, art. 3, e170025, 2017

http://dx.doi.org/10.1590/1807-7692bar2017170025

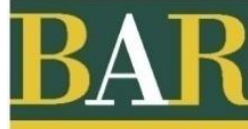

Brazilian

Administration

Review

\title{
Does Operational Risk Disclosure Quality Increase Operating Cash Flows?
}

Haitham Nobanee ${ }^{1,2}$

Nejla Ellili ${ }^{1}$

Abu Dhabi University ${ }^{1}$ University of Liverpool ${ }^{2}$

Received 6 March 2017; received in revised form 6 November 2017 (this paper has been with the authors for two revisions); accepted 8 November 2017; first published online 12 December 2017. Editor's note. Luiz Eduardo Teixeira Brandão served as Action Editor for this article. 


\begin{abstract}
This study aims to measure the degree of operational risk disclosure and examine its impact on operating cash flow of banks listed on the UAE Abu Dhabi Stock Exchange (ADX) and Dubai Financial Market (DFM) during the period 2003-2016. The authors conducted content analysis of the annual reports to measure the degree of operational risk disclosure. In addition, they used dynamic panel data regressions to analyze the impact of operational risk disclosure on the operating cash flow generated by the banks. The results show a low degree of operational risk disclosure for all UAE banks, both Islamic and conventional. In addition, the results show no association between the levels of disclosure of operational risk and cash flow for all banks, conventional and Islamic. Operational risk disclosure of Islamic banks has not been examined by any prior researchers. In addition, this paper examines the potential impact of operational risk disclosure on the operating cash flow generated by the banks.
\end{abstract}

Key words: operating cash flow; operational risk disclosures; annual reports; dynamic panel data analysis. 


\section{Introduction}

The banking system plays a dynamic role in every economy, has a central impact on overall economic performance, and had a major involvement in the extensive financial crisis (Kabir, Worthington, \& Gupta, 2015). In effect, effective operational risk management helps banks in, among others, avoiding disastrous financial losses, accurately measuring performance, restructuring products and services, and ensuring persistence in case of takeovers. In addition, operational risk management is considered an important condition, among others, for enhancing the stability and ensuring the sustainability of the banking sector. After the recent financial crisis, operational risk management has gained attention from regulators requiring a better understanding of critical risks and more transparency in managing the operational risk with the objective to strengthen confidence in the banking system.

In the finance literature, there are many studies exploring the extent of the general risk disclosure but few exploring operational risk disclosure, including: Linsley and Shrives (2006) in UK and Canada; Helbok and Wagner (2006) in North America, Asia and Europe; Oliveira, Rodrigues and Craig (2011) in Portugal; Hemrit and Ben Arab (2011) in Tunisia; Haija and Hayek (2012) in Jordan; Barakat and Hussainey (2013) in Europe; Herghiligiu (2013) in Romania; and Barakat Chernobai and Wahrenburg (2014) in the USA.

In the particular context of the emerging market economy of the United Arab Emirates (UAE), there are only researches about general risk disclosure in annual reports and not specifically about operational risk, such as Hassan (2009) and Hassan (2014). Hassan (2009) examines the relationship between UAE corporations-specific characteristics (size, level of risk, industry type and reserves) and the level of corporate risk disclosure by using a sample of 49 companies for 2005 . His empirical findings reveal that the extent of the risk disclosure is significantly affected by the level of risk and reserves. In the same context, Hassan (2014) explores the extent of the narrative risk disclosure in 23 annual reports of UAE financial institutions for 2008 and examines how societal expectations of the UAE stakeholders are related to risk disclosures. His results show that the UAE financial institutions use their risk disclosure to gain, maintain and restore their social legitimacy.

Although our paper has some similarities with the previous studies regarding the exploration of risk disclosure in annual reports, it goes further to examine the extent of the specific operational risk disclosure. In addition, our study analyses the impact of the operational risk disclosure on operating cash flow by differentiating between Islamic and conventional banks. This is a very attractive research opportunity because, in the UAE, there is an emphasis on forcing all listed banks to comply with the best practices of risk disclosure, on one side, and efficiently manage their cash flows, on the other.

Even though Islamic banks' products may be similar to conventional banks' products, the two banking systems differ significantly. The major difference between the two banking systems is that conventional banks make their money by charging interest and also by charging fees for services, while Islamic banks make their money by profit and loss sharing, trading, and leasing, in addition to charging fees for services and using other sharia-based contracts of exchange (Jamaldeen, n.d.). Islamic banking has achieved high growth rates in the past few years, the top 500 Islamic Financial Institution (TIFI) listing indicates that the 2012 total of Shariah-compliant assets grew by 29.7\% over 2011 (Banker, 2013 as cited in Daly \& Frikha, 2016). Islamic banks currently hold about $\$ 2.5$ trillion of global bank assets (Daly \& Frikha, 2016).

Against this background, we conduct this research with the following main questions. First, to what extent do the UAE listed banks disclose their operational risk in their annual reports? Second, is there any significant difference between Islamic and conventional banks in their risk disclosure? Third, is there any significant impact of the operational risk disclosure on the operating cash flow of the banks?

Our paper contributes to the existing literature on operational risk disclosure in two important ways. First, our study focuses not only on conventional banks but also on Islamic banks, whereas most of previous researches have focused on exploring the operational risk disclosure in conventional banks 
(Barakat \& Hussainey, 2013; Helbok \& Wagner, 2006; Herghiligiu, 2013; Oliveira, Rodrigues, \& Craig, 2011). Hence, the operational risk disclosure of Islamic banks needs to be explored as well, since this type of banks is also concerned with operational risk management. Second, our study fills the gap in risk management literature concerning the possible association between the extent of operational risk disclosure and the operating cash flow generated by banks. In addition, our research will shed light on the operational risk disclosure areas that need further improvement, and recommend that UAE regulatory authorities implement more effective mechanisms to enhance compliance with the best practices of corporate disclosure. Our findings will help the central bank develop an operational credit risk framework and guideline to address areas of weaknesses in terms of operational risk management and exploit the sources of strength in terms of operating cash flow within the UAE banking system. To our knowledge, there is no single research conducted in the UAE about the extent of the operational risk disclosure in the annual reports of the banks, so our research will illuminate this topic.

The results of the content analysis show a low degree of operational risk disclosure index for both Islamic and conventional UAE banks. The effect of the degree of operational risk disclosure on operating cash flow is examined by applying the robust Generalized Method of Moment System Estimation (GMM) to dynamic panel data. The results of the GMM show that the higher the disclosure of the operational risk, the higher the operating cash flow for all UAE-listed banks.

These results contribute by providing a better knowledge about the level of the operational risk disclosure of the banks in the UAE as well as a deep understanding of the impact of the operational risk disclosure on the operating cash flow generated by the banks. This would help the banks to optimally disclose their risks, enhance the quality of their disclosure practices, improve the quality of their financial reports, and more efficiently manage their cash flows.

The remainder of the paper is organized as follows: Second section contains a literature review about the importance of operational risk disclosure in risk management. Third section focuses on data and the empirical methodology. Fourth section presents the empirical results and finally the conclusion is given in fifth section.

\section{Literature Review}

Operational risk is defined as "the risk of direct or indirect loss resulting from inadequate or failed internal processes, people, and systems or from external events" (Bank for International Settlements, 2001, p. 2). In effect, operational risk is integral in all banking products, processes, and systems, and the effective management of operational risk is considered to be a fundamental element of a bank's risk management process (Bank for International Settlements, 2011). Therefore, banks should use their public disclosure to allow stakeholders to assess their risk management mechanisms.

In the risk management literature, there are only a few studies exploring the extent of operational risk in annual reports (Barakat \& Hussainey, 2013; Barakat, Chernobai, \& Wahrenburg, 2014; Haija \& Hayek, 2012; Helbok \& Wagner, 2006; Hemrit \& Ben Arab, 2011; Herghiligiu, 2013; Linsley \& Shrives, 2006; Oliveira et al., 2011).

Managing operational risk in financial institutions has been much more important in recent years. Effective operational risk management in financial institutions plays a significant rule in enhancing the competitiveness of financial institutions and financial stability and reducing the likelihood of bankruptcy (Zhang, 2008).

\section{The extent of operational risk disclosure}

The concept of risk and the importance of the risk management process have received considerable attention in many researches, but Linsley and Shrives (2006) are the first who examine a 
firm's risk disclosure practices by exploring the risk information in the annual reports of 79 UK nonfinancial companies by using content analysis. In their exploration of risk disclosure, they consider three types of risks: strategic risk related to the external business environment, financial risk associated with the company's financial position, and operational risk related to the internal business functions. Content analysis indicates that the companies disclose more information about strategic risk than operational and financial risks. In addition, the findings reveal that the level of overall risk disclosure is positively associated with company size.

More specifically, Haija and Hayek (2012) examine the items of operational risk disclosed by Jordanian commercial banks and investigate whether they comply with the Central Bank of Jordan requirements. By exploring the content of the annual reports of 12 Jordanian commercial banks, their findings show that the banks comply with the Central Bank requirements related to operational risk disclosure information, but there is no consensus among the banks on the way they disclose the operational risk information in their annual reports. As such, Jordanian banks should adhere to the operational risk information regulations. Similarly, Herghiligiu (2013) explores the extent of operational risk disclosure in the annual reports of 41 Romanian commercial banks. By using a disclosure index, the findings show that the extent and content of the operational risk information are at low level. In addition, the annual reports of Romanian banks are not in compliance with the requirements of the National Bank of Romania relating to operational risk disclosure. In addition, there are many discrepancies between Romanian banks in terms of the presentation of the operational risk information in their annual reports, as they do not disclose the same types of operational risk information. Herghiligiu (2013) advises Romanian commercial banks to increase prevailing operational risk disclosure proceedings.

In a further analysis, Barakat et al. (2014) do not only explore the operational risk disclosures of the financial firms, but go further in examining the impact these disclosures have on the information asymmetry in the companies' equity markets. By analyzing the operational risk disclosure of US financial firms during the period 1995-2009, the empirical results reveal that the first press-cutting operational risk announcements increase information asymmetry measured by the effective bid-ask spreads and the price impact of trades, while settlement announcements decrease the information asymmetry. In addition, it has been found that stronger corporate governance structure reduces the information asymmetry around operational risk disclosure. More particularly, the reduction in information asymmetry is associated with board independence, equity incentives and institutional ownership.

\section{Determinants of operational risk disclosure}

Helbok and Wagner (2006) investigate the determinants of the voluntary disclosure practices of operational risk of 59 financial institutions in North America, Asia and Europe during the period 19982001. To evaluate the extent and content of operational risk disclosure, a disclosure index has been constructed by including 22 items: 7 items related to the definition of operational risk, 10 items related to the risk management process, and 4 items related to regulatory issues. Their empirical results indicate that financial institutions with lower equity and profitability ratios give higher importance to disclosing their operational risk information. These results suggest that financial institutions with a lower capital ratio have a higher incentive to disclose their operational risk as strong evidence of their proper risk management process with the objective of reducing their perceived agency, financial distress and political costs.

In the same spirit of research, Hemrit and Ben Arab (2011), assess the level of operational risk disclosure and examine its main determinants in Tunisian Insurance companies during the period 20002009. Their empirical findings show that the level of operational risk disclosure increased slightly during the analysis period. In addition, they indicate that the level of operational risk disclosure is significantly and positively influenced by the size of the company, as well as the intensity of its provisions and its leverage, while the profitability and cost of capital do not have any significant impact on the level of operational risk disclosure. 
Furthermore, Oliveira et al. (2011) do not only examine the factors affecting operational risk disclosure in the annual reports of 111 Portuguese banks for 2006, but go further to explore the conformity of these reports with Basel II requirements related to the voluntary operational risk disclosure. By considering legitimacy theory, the empirical results indicate that the public visibility of the bank (measured by size and listing status) and its reputation (measured by age, stakeholders depositors and risk management abilities) are central factors promoting operational risk disclosure, as the publicly visible and reputational banks are exposed to strong institutional pressure to disclose their operational risk information and comply with disclosure requirements.

\section{Corporate governance mechanisms and operational risk disclosure}

Barakat and Hussainey (2013) examine the impact of corporate governance mechanisms on the quality of operational risk disclosures in the annual reports of 63 publicly-listed European banks for the years 2008 and 2009. By using panel data regressions, their empirical results reveal that banks with a higher proportion of outside members on their board of directors are associated with higher operational risk disclosure quality. In addition, the results clarify that agency theory offsets management entrenchment theory in banks, as they show a positive association between the proportion of outstanding shares held by executive directors and operational risk disclosure quality. Furthermore, the study shows a positive relationship between a rigid legal system and the enforcement of senior management in providing their stakeholders with high quality operational risk information. Overall, this study confirms the positive impact of effective corporate governance mechanisms on operational risk disclosure quality, as well as the importance of considering the impact legal systems have on operational risk disclosure.

In the UAE, the Central Bank issued a Circular $N^{\circ} 27 / 2009$ dated November 17, 2009, requiring all banks to conform to Basel II Capital adequacy calculation (Central Bank of the U. A. E., 2009). The intention of Basel II, initially published in June 2004, is to create an international standard for banking regulators to control the capital the banks have to put aside to face financial and operational risks, to maintain sufficient consistency of regulations among international banks, and help to protect the international financial system from the types of problems that might arise. The focus of Basel is to accomplish these intentions by setting up risk and capital management requirements designed to ensure that banks have adequate capital to face any risk from their lending and investment practices. These rules mean that the greater risk to which the banks are exposed, the greater the amount of capital the banks need to hold to safeguard their solvency and overall economic stability. From 2013 on, the Central Bank of UAE requires all local lenders to comply with Basel III banking supervision standards by holding 10 percent of their liabilities in liquid assets (Central Bank of the U. A. E., 2012). High-quality liquid assets include cash, certificates of deposit, and highly-rated local government bonds.

In our analysis, we assume that a higher level of operational risk disclosure in the annual reports would improve the risk management practices of banks, enhance their liquidity, and maintain the trust of their stakeholders.

Hypothesis: There is a positive association between the quality of operational risk disclosure and the operating cash flow generated by the banks.

\section{Methodology}

This study aims to explore the extent of operational risk disclosure in the annual reports of banks and examine its potential effect on operating cash flow generated by all UAE-listed banks, and then specifically that by UAE Islamic banks and conventional banks. In our analysis, we adopt a four-stage method to respond to our three research objectives. In the first step, we use content analysis to measure the degree of operational risk disclosure in the annual reports for all UAE banks, and then Islamic and conventional UAE banks. We also employ the one sample t-test to investigate whether operational risk disclosures are significantly above 50\% for all, Islamic, and conventional UAE banks. In the second 
step, we compare operational risk disclosure between Islamic and conventional banks using Mann Whitney test. In the third step, we measure operating cash flow using the ratio of operating cash flow to total assets for all, Islamic and conventional banks, and we test for significant differences in operating cash flow between Islamic and conventional banks. In the final step, we test the potential effect of the degree of operational risk disclosure on operational cash flow for all, Islamic and conventional UAE banks by using robust Generalized Method of Moment System Estimation (GMM) applied to dynamic panel data. In our regression, size and leverage have been added to our estimation as control variables.

\section{Data}

The data was hand collected from UAE listed banks' annual reports for the 2003-2016 period. Our final sample includes all banks listed on both the Dubai financial market and Abu Dhabi securities market (for a total of 224 firm-year observations).

\section{Operational risk disclosure measurement}

The operational risk disclosure index developed by Linsley and Shrives (2006) was used in this study and the operational risk disclosure categories/items are presented in Table 1.

Table 1

\section{Operational Risk Disclosures Index}

\begin{tabular}{ll}
\hline Item $\mathbf{N}^{\mathbf{0}}$ & Category/Item of disclosure \\
\hline 1 & Dependence on the know-how of the personnel \\
\hline 2 & Uncommon business fluctuations in demand \\
\hline 4 & Interruptions in the delivery chain \\
\hline 5 & Price fluctuations of the factors of production \\
\hline 6 & Patents and other industrial property rights \\
\hline 7 & Customer satisfaction \\
\hline 9 & Information technology risks \\
\hline 10 & Reputation and brand name development \\
\hline 11 & Stock obsolescence and shrinkage \\
\hline 12 & Product and service failure \\
\hline 13 & Environmental \\
\hline 14 & Health and safety \\
\hline
\end{tabular}

Note. Source: Linsley, P. M., \& Shrives, P. J. (2006). Risk reporting: A study of risk disclosures in the annual reports of UK companies (p. 15). The British Accounting Review, 38(4), 387-404. https://doi.org/10.1016/j.bar.2006.05.002

The degree of operational risk disclosure was measured for all, Islamic and conventional UAElisted banks using the items shown in Table 1. We measure scores and means for the operational disclosure index. The values of the operational risk disclosure range between $0 \%$ and $100 \%$. A value of $0 \%$ means no operational risk disclosure by the banks, while a value of $100 \%$ means a full operational risk disclosure. We employ the following relative index approach for the operational risk disclosure index: 
OPINDEX $=\sum_{i=1}^{m} D i / \sum_{i=1}^{n} D i$

Where:

- OPINDEXi = Operational risk disclosure;

- $\mathrm{D}=1$ if item $\mathrm{i}$ is disclosed, and 0 otherwise;

- $\mathrm{n}=$ aggregation of all applicable items

- $\mathrm{m}=$ number of actual items disclosed

\section{Estimation techniques}

We employ the Mann-Whitney test to examine the differences between conventional and Islamic banks in terms of overall operational risk disclosure. In addition, we use the one sample t-test and means of the operational risk disclosure index to measure whether the operational risk disclosure is significantly above $50 \%$.

To examine the effect of the level of operational risk disclosure on operational cash flow for all, Islamic and conventional UAE banks, we employ the robust Generalized Method of Moment System Estimation (GMM) applied to dynamic panel data as recommended by Arellano and Bover (1995) and Blundell and Bond (1998). We also consider the finite sample correction suggested by Windmeijer (2005) in our estimation. We chose this estimation technique because it controls for possible endogeneity issues and the possibility of unobserved province-specific effects correlated with the independent variables. The robust GMM does not require any quality or diagnostic tests.

The estimation method leads to the following estimation equation:

$$
\text { OCFA }_{i t}=\alpha+\beta_{1} \text { OBCFA }_{i t_{-1}}+\beta_{2} \text { TLTA }_{i t_{-1}}+\beta_{3} \text { LGTA }_{i t_{-1}}+\beta_{4} \text { OPINDEX }_{i t_{-1}}+\varepsilon_{i t}
$$

In our model, the dependent variable and the independent variables are in the form of first difference:

- The $\left(O B C F A_{i t}\right)$ is the first difference of operating cash flow to total assets;

- The $\left(O B C F A_{i t_{-1}}\right)$ is the differenced lagged dependent variable;

- The (OPINDEX $\left.{ }_{i t_{-1}}\right)$ is the first difference of operational risk disclosure;

- The $\left(T L T A_{i t_{-1}}\right)$ is the control variable of leverage measured by the first difference of total liabilities to total assets;

- The $\left(L G T A_{i t_{-1}}\right)$ is the control variable of size measured by the first difference of logarithm of total assets;

. The $\left(\varepsilon_{i t}\right)$ is the error term.

\section{Empirical Results}

We present below our descriptive statistics and estimation results concerning levels of operational risk disclosure of all, Islamic and conventional UAE banks for the period 2003-2016. Table 2 includes 
means of operational risk disclosure index for all banks, and also separately for conventional banks and Islamic banks. The descriptive statistics results show higher operational cash flow to total assets for conventional banks as compared with Islamic banks. The results also indicate that the operational risk disclosure of UAE banks is, in general, at a low level for all, Islamic, and conventional banks. Furthermore, the Islamic banks have lower leverage compared with conventional banks and conventional bank size is larger than that of Islamic banks.

Table 2

\section{Descriptive Statistics}

\begin{tabular}{llll}
\hline Mean & All Banks & Conventional Banks & Islamic Banks \\
\hline Operational Risks Disclosure & 0.225756 & 0.2387755 & 0.1830357 \\
\hline Operational Cash Flow & 0.1192949 & 0.1423943 & 0.0578712 \\
\hline Size & 7.642859 & 7.657224 & 7.605509 \\
\hline Leverage & 2.532066 & 3.173908 & 0.8632753 \\
\hline
\end{tabular}

Note. Table 2 reports the descriptive statistics showing the mean of different variables for all banks, conventional banks, and Islamic banks.

Table 2 reports the means of operational risk disclosure, operational cash flow, size and leverage of all banks, Islamic and conventional banks listed on UAE financial markets during the period 20032016. The value of the operational risk disclosure index ranges between $0 \%$ and $100 \%$. A value of $0 \%$ means no corporate risk disclosure by the bank while a value of $100 \%$ means a full corporate risk disclosure. Operational cash flow is measured by operational cash flow to total assets, leverage is measured by total liabilities to total assets, and size is measured using the logarithm of total assets.

The results of the one sample t-test reported in Table 3 support the results of the descriptive statistics reported in Table 2. The results show that operational risk disclosures for all, Islamic and conventional banks are not significantly higher than the index average of 50\%.

Table 3

One Sample t-test of Operational Risk Disclosure of UAE Banks

\begin{tabular}{llll}
\hline $\mathrm{t}$ value & All Banks & Conventional Banks & Islamic Banks \\
\hline Operational Risks Disclosure & -22.0195 & -17.8642 & -14.4251 \\
\hline
\end{tabular}

Note. Table 3 reports one sample t-test of operational risk disclosure of all banks, Islamic and conventional banks listed on UAE financial markets during the period 2003-2016.

* Significant at $95 \%$ confidence level, **significant at $99 \%$ confidence level.

The results of the Mann-Whitney test reported in Table 4 confirm that the operational risk disclosure has insignificant differences between conventional and Islamic banks. The results also show size and operating cash flow have insignificant differences between UAE Islamic and conventional banks, while the results show significant differences in leverage between the two banking systems. 
Table 4

\section{Mann-Whitney Test Results}

\begin{tabular}{ccccc}
\hline $\begin{array}{c}\text { Mann-Whitney- } \\
\text { test }\end{array}$ & $\begin{array}{c}\text { Operational Risks } \\
\text { Disclosure }\end{array}$ & $\begin{array}{c}\text { Operational Cash } \\
\text { Flow }\end{array}$ & Leverage & Size \\
\hline Z Value & 1.807 & -0.501 & $-3.248 * *$ & 0.544 \\
\hline
\end{tabular}

Note. Table 4 reports the results of Mann-Whitney test of operational risk disclosure, operational cash flow, size and leverage of all banks, Islamic and conventional banks listed on UAE financial markets during the period 2003-2016. Operational risk disclosure measured use the index described in Table 1, operational cash flow measured by operational cash flow to total assets, leverage is measured by total liabilities to total assets, and size is measured using the logarithm of total assets.

* Significant at $95 \%$ confidence level, **significant at $99 \%$ confidence level.

Table 5 includes the results of the robust dynamic panel-data two- steps GMM system estimation of the relationship between the level of operational risk disclosure and operational cash flow for all, Islamic, and conventional UAE banks. The results of the lagged dependent variable for all banks, conventional banks, and Islamic banks indicate that a bank's operational cash flow in the previous period has no significant effect on the bank's operational cash flow in the current period. The operational risk disclosure showed an insignificant effect on operational cash flow for all banks, conventional banks, and Islamic banks. The results of the size variable show insignificant effect on operational cash flow for all, Islamic, and conventional banks. This result contradicts those of previous studies (Hemrit \& Ben Arab, 2011; Linsley \& Shrives, 2006; Oliveira et al., 2011). However, the leverage variable shows significant impact on operating cash flow for conventional banks, this result corroborates the findings of Helbok and Wagner (2006). However, leverage has an insignificant impact on operating cash flow for all banks. The leverage variable of Islamic bank is omitted by the estimation because of collinearity.

Table 5

\section{Results of Robust Dynamic Panel-Data Two- Steps GMM System Estimation of Operational Corporate Risk Disclosure Index}

\begin{tabular}{llll}
\hline Dependent: Operational Cash Flow & All Banks & Conventional Banks & Islamic Banks \\
\hline Lag Dependent & -0.0025758 & -0.0015842 & -2.548663 \\
\hline Operational Risks Disclosure & -0.0182105 & -0.0161441 & -0.2957606 \\
\hline Size & 0.0051410 & 0.0405521 & -0.1239228 \\
\hline Leverage & 0.0384824 & $0.0388516 * *$ & (omitted) \\
\hline
\end{tabular}

Note. Table 5 reports the results of robust dynamic panel-data two- steps GMM system estimation for the relationship between the degree of the operational risk disclosure on operational cash flow of all banks, Islamic and conventional banks listed in the UAE financial markets during the period 2003-2016. Dependent variable and independent variables are in the form of first difference. Operational risk disclosure measured use the index described in Table 1, operational cash flow measured by operational cash flow to total assets, leverage is measured by total liabilities to total assets, and size is measured using the logarithm of total assets.

* Significant at $95 \%$ confidence level, **significant at $99 \%$ confidence level.

\section{Conclusion}

In our paper, we aimed to empirically examine the extent of operational risk disclosure in the annual reports of banks listed on UAE financial markets during the period 2003-2016. After conducting the content analysis, we found evidence that the all banks the in UAE (conventional or Islamic) disclose low information about their operational risk in their annual reports with a slight difference in the level of disclosure between the conventional and Islamic banks. In addition, the dynamic panel regressions 
showed no relationship between the level of operational risk disclosure and the operating cash flow generated by all banks, Islamic banks, and conventional banks. Moreover, our findings reveal that the size of the bank does not have any significant effect on operational cash flow for all, Islamic, and conventional banks. This result is in contradiction with the results of previous studies and suggests that public visibility is not considered by the banks as a pressure to disclose their operational risk information and that the banks have other incentives, such as stakeholder's trust, to enhance their risk disclosure practices. However, the leverage variable shows significant positive impact on operating cash flow for conventional banks. This results corroborate those of previous studies suggesting that banks with higher leverage are exposed to higher public pressures from stakeholders to disclose more information about their operational risk.

Practically, our findings recommend that banks should enhance their operational risk disclosure practices to improve their risk management process as well as their stability and sustainability over the time. Another practical implication is to recommend that the UAE Central Bank focus more of its efforts on controlling and promoting the operational risk disclosure of all banks and making sure that banks' disclosure practices comply with Basel accords. The UAE Central Bank is recommended to develop a framework to guide the banks to optimally disclose their risks, enhance the quality of their disclosure practices, improve the quality of their financial reports and more efficiently manage their cash flows.

Finally, our research points to avenues for future researches on this topic which could consider the potential impact of corporate governance mechanisms, such as ownership structure and the board of directors, on the level of operational risk information and the compliance of risk disclosure with the Central Bank requirements. Furthermore, it would be very interesting to examine the potential impact on the cost of equity and cost of debt for the banks.

\section{References}

Arellano, M., \& Bover, O. (1995). Another look at the instrumental variable estimation of error component models. Journal of Econometrics, 68(1), 29-51. https://doi.org/10.1016/03044076(94)01642-d

Bank for International Settlements. (2001, January). Operational risk. Retrieved from https://www.bis.org/publ/bcbsca07.pdf

Bank for International Settlements. (2011, June). Principles for the sound management of operational risk. Retrieved from http://www.bis.org/publ/bcbs195.pdf

Barakat, A., \& Hussainey, K. (2013). Bank governance, regulation, supervision, and risk reporting: Evidence from operational risk disclosure in European banks. International Review of Financial Analysis, 30, 254-273. https://doi.org/10.1016/j.irfa.2013.07.002

Barakat, A., Chernobai, A., \& Wahrenburg, M. (2014). Information asymmetry around operational risk announcements. Journal of Banking and Finance, 48, 152-179. https://doi.org/10.1016/j.jbankfin.2014.06.029

Blundell, R., \& Bond, S. (1998). Initial conditions and moment restrictions in dynamic panel data models. Journal of Econometrics, 87(1), 115-143. https://doi.org/10.1016/s0304-4076(98)00009-8

Central Bank of the U. A. E. (2009, November). Capital adequacy standards - Standardised approach. Retrieved from https://www.centralbank.ae/pdf/baselII/Basel2-Guidlines.pdf

Central Bank of the U. A. E. (2012, July 12). Liquidity regulations at banks (Circular No.: 30/2012). Retrieved from http://www.centralbank.ae/en/pdf/notices/CircularNo-302012LiquidityRegulationsAtBanks.pdf 
Daly, S., \& Frikha, M. (2016). Banks and economic growth in developing countries: What about Islamic banks? Cogent Economics \& Finance, 4(1), 1168728. https://doi.org/10.1080/23322039.2016.1168728

Haija, M. F. A. E., \& Hayek, A. F. A. (2012). Operational risk disclosures in Jordanian commercials banks: It's enough. International Research Journal of Finance and Economics, 83, 50-61.

Hassan, M. K. (2009). UAE corporations-specific characteristics and level of risk disclosure. Managerial Auditing Journal, 24(7), 668-687. https://doi.org/10.1108/02686900910975378

Hassan, M. K. (2014). Risk narrative disclosure strategies to enhance organizational legitimacy: Evidence from UAE financial institutions. International Journal of Disclosure and Governance, 11(1), 1-17. https://doi.org/10.1057/jdg.2012.11

Helbok, G., \& Wagner, C. (2006). Determinants of operational risk reporting in the banking industry. The Journal of Risk, 9(1), 49-74. https://doi.org/10.21314/jor.2006.140

Hemrit, W., \& Ben Arab, M. (2011). The disclosure of operational risk in Tunisia insurance companies. Journal of Operational Risk, 6(2), 69-111. https://doi.org/10.21314/jop.2011.089

Herghiligiu, R. (2013). Operational risk disclosure in Romanian commercial banks. Journal of Public Administration, Finance and Law, 4, 171-178. Retrieved from http://www.jopafl.com/uploads/issue4/OPERATIONAL_RISK_DISCLOSURE_IN_ROMANI AN_COMMERCIAL_BANKS_1.pdf

Jamaldeen, F. (n.d.). Four ways conventional and Islamic commercial banks differ. Dummies. Retrieved from http://www.dummies.com/personal-finance/islamic-finance/four-ways-conventional-andislamic-commercial-banks-differ/

Kabir, M., Worthington, A., \& Gupta, R. (2015). Comparative credit risk in Islamic and conventional bank. Pacific-Basin Finance Journal, 34(C), 327-353. https://doi.org/10.1016/j.pacfin.2015.06.001

Linsley, P. M., \& Shrives, P. J. (2006). Risk reporting: A study of risk disclosures in the annual reports of UK companies. The British Accounting Review, 38(4), 387-404. https://doi.org/10.1016/j.bar.2006.05.002

Oliveira, J., Rodrigues, L. L., \& Craig, R. (2011). Voluntary risk reporting to enhance institutional and organizational legitimacy: Evidence from Portuguese banks. Journal of Financial Regulation and Compliance, 19(13), 271-288. https://doi.org/10.1108/13581981111147892

Windmeijer, F. (2005). A finite sample correction for the variance of linear efficient two-step GMM $\begin{array}{llll}\text { estimators. } \quad \text { Journal } & \text { 25-51. }\end{array}$ https://doi.org/10.1016/j.jeconom.2004.02.005

Zhang, S. (2008). The study on operational risk measurement methods of commercial bank in China (Master thesis). Retrieved from ProQuest Dissertations and Theses database (10449006). 


\section{Authors' Profiles}

Haitham Nobanee

Abu Dhabi University - Finance and Economics, Al Ain Road, Abu Dhabi, 59911, United Arab Emirates. E-mail address: nobanee@gmail.com. http://orcid.org/0000-0003-4424-5600

Nejla Ellili

Abu Dhabi University - Finance and Economics, Al Ain Road, Abu Dhabi, 59911, United Arab Emirates. E-mail address: nejla.ellili@adu.ac.ae 